\title{
AUTOMATIC GENERATION OF HACHURE LINES
}

\author{
Zsolt MAGYARI-SÁSKA ${ }^{1}$
}

DOI: 10.21163/GT_2017.121.08

\begin{abstract}
:
Creating hachure maps was a well-known and widely used method in cartography for relief representation, which has served mainly military purposes. With this method gradients are represented instead of elevation. Starting from the $20^{\text {th }}$ century, hachure based representations were abandoned and replaced by contour lines based representations. However the apart graphical aspect of hachure maps and the fact that they emphasizes the slope characteristics, makes them useful in various fields (ex. archeology, education and museology) even today. In the reconstruction process of a historical map with hachures the hachure lines hardly can be digitized especially due to their enormous number. In this paper we present a possibility to recreate hachure lines using GIS methodology respecting their construction rules as much as it's possible.
\end{abstract}

Key-words: Hachure, Historical map, Automatic generation, Relief representation.

\section{INTRODUCTION}

Starting with the conceptual change in cartography to represent the relief using perpendicular view instead of in the side view, to not cover important places on a map new ways of relief representations had to be adopted. The first attempts were made by Samuel Schmettau, Ludwig ChristianMüller based on Cassini's ideas in the second part of the $18^{\text {th }}$ century (Harsányi, 2010). The subsequently developed methodology led to hachure maps, which were well-known and widely used in the cartography of $18-19^{\text {th }}$ century (Collier et al., 2003; Räber et al., 2009). They are based on hachure lines which represents the gradient instead of elevation. This way of relief representation served mainly military purposes as the absolute elevation was less important than the gradient value of battlefield where army troops and military machinery had to move. This way of representing the relief sometimes is called as the first attempt of modern 3D representation (Marston, 2015).

There are two ways of representing the relative slope's value using hachure lines: varying the lines thickness or changing their density (Hicking, 2014). In both cases the desired result was to darken the areas with higher slope, indicating their harder accessibility (Mélykúti, 2010). With this representation method the map wouldn't had any elevation indicator, thus in some places punctual height values were placed. Even with this, hachure based representation offers an easy way to identify some morphological elements as pikes, valleys, cols (Niculescu, 2003). In modern cartography, with the discovery of lithography, having the possibility to print shades, and even more with the appearance of modern $3 \mathrm{D}$ representation methods, it seems that hachure based representation is quenched. However there are fields where hachure can be useful. One of them is surely archeology where sketches of archeological sites using hachure lines are used even today (O'Loughlin \& Mackaness, 1999). In this paper we present an automatic way to recreate hachure lines using GIS methodology respecting their construction rules as much as it's possible.

\footnotetext{
${ }^{\text {I} B a b e s ̦-B o l y a i}$ University, 535500 Gheorgheni, Romania, zsmagyari@gmail.com
} 


\section{METHODS AND DATA}

Automatized techniques in digital cartography are widely used. A significant part of them refers to automatic symbol and label placing so that map content not to be covered. In the past years also automatic content generation is a development direction (Hurni et al., 2001; Lysák, 2015, 2016) which can include also hachure line generation. In the scientific literature we can find several attempts to recreate hachure maps in an automated way. The two main leading scientific fields in that direction are represented by historical digital cartography, wanting to create old fashion like maps or to reconstruct the originals, and by archeology, where slope representation is desired and it's highly relevant.

The first who used hachure lines was Johann Georg Lehmann in 1799, his methodology was later standardized by Imhof (2007) for modern representation. Lehmann's original method has the restriction that hachure lines should have at most $4 \mathrm{~mm}$ length, but not shorter than the side by side distance between them. The line should follow the slope's direction and should be arranged in rows. Subsequent rows should not follow each other lines, just only in exceptional cases. The thickness of the lines were arranged in 8 classes, areas with slope below 5 degrees were not hachured (Harsányi, 2010). The representable slopes were from 5 to 45 degrees, that's why Speich (2009) proposed new thickness classes for areas with steeper slope. In time several other attempts were made regarding the line thickness assessment but they did not spread out and have failed over time.

The main rules of Imhof for constructing a hachure map are:

- the lines should follow the slope direction

- the lines are arranged in rows

- the line's length is equal with their bee line

- the line'sthickness is proportional with the slope's value

- the density of hachure is constant

The hachure representation is better for large-scale maps (Robinson, 1995), that's why Kennelly and Kimerling (2000) suggest the relaxation of Imhof's rules for small scale maps, not considering mandatory the second and third rule. Using GIS to automatically generate hachure lines a staring data model should be chosen. In present there are studies which works on vector data model (O’Loughlin \& Mackaness, 1999; Yoeli, 1985) and also are attempts using raster data model (Kennelly \& Kimerling, 2000).

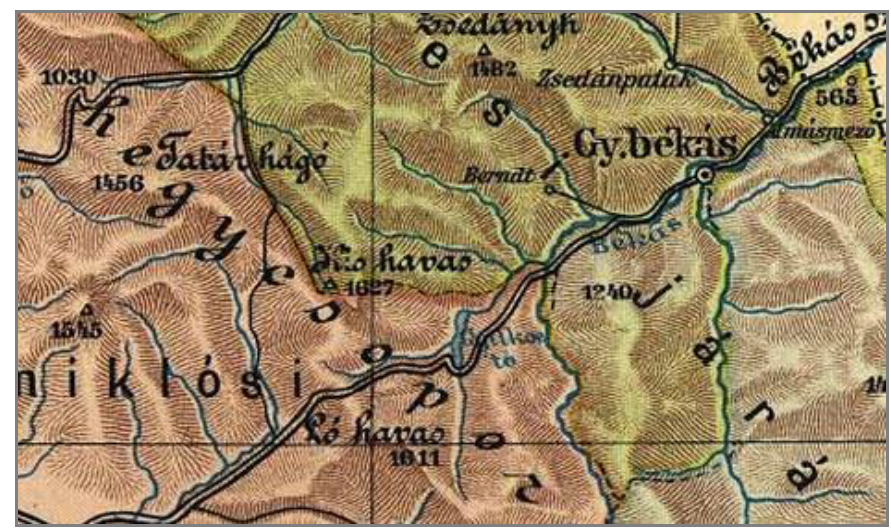

Fig. 1 Part of the test area with hachure lines 
In our current research we have chosen a raster data model based representation. We used the SRTM 1 elevation grid to perform the computation. As test area, we have chosen a generalized map sheet of the Habsburg Empire's third military survey, representing a mountainous region in the Eastern Carpathians (Fig. 1). The map's scale is 1:400.000 which is considered a small scale map. It's important to mention, that hachuring represents an artwork, realized for a given scale, so it's a scale dependent representation.

\section{ALGORITHM AND DISCUSSION}

As starting data the SRTM 1 arc second resolution digital elevation model (DEM) was used. The schematic view of the full process is presented in Fig. 2 and described below.

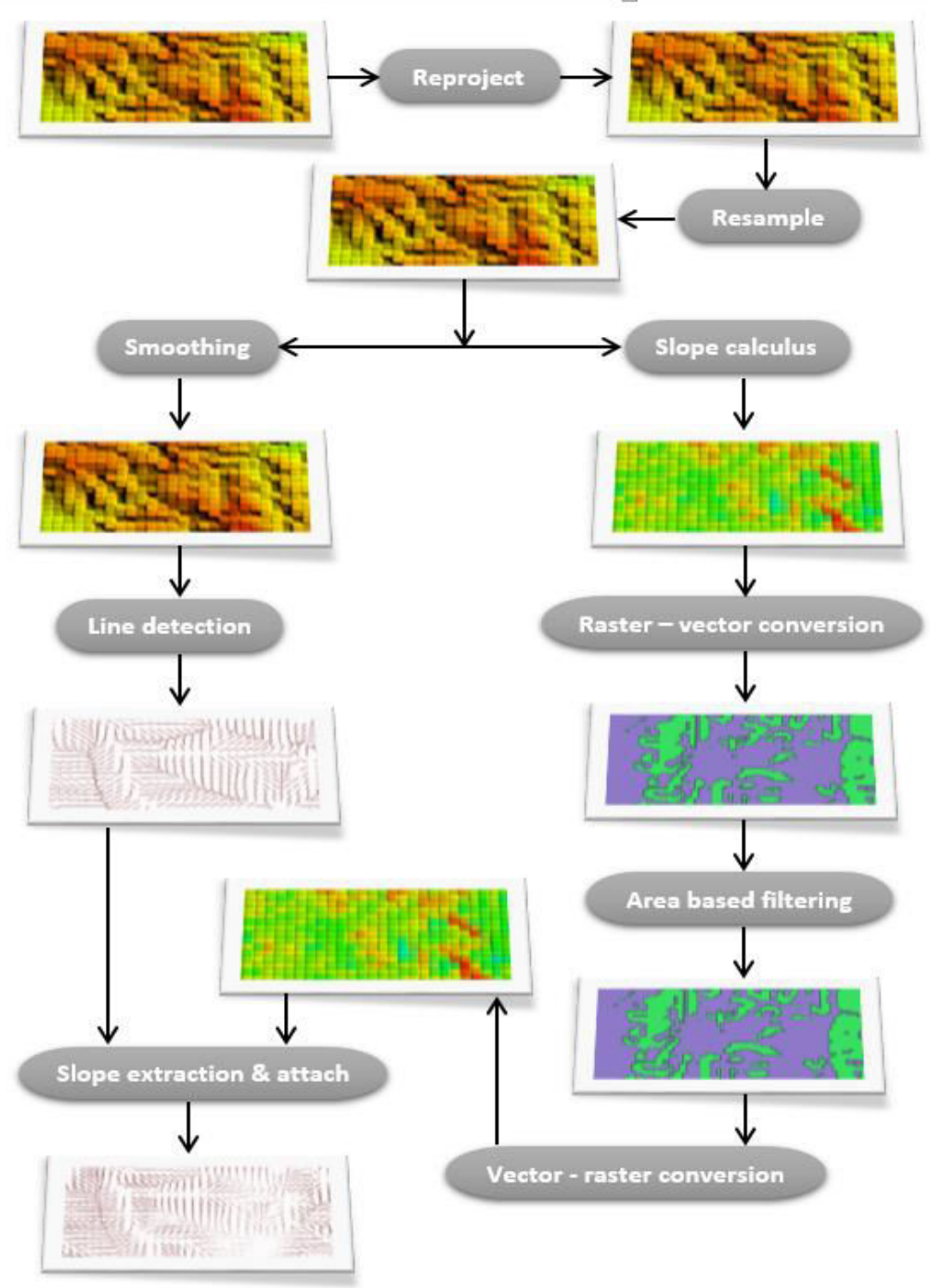

Fig. 2. The developed algorithm 
As the result to can be displayed on OpenStreetMaps for checking some details, the SRTM data was converted from WGS84 in EPSG 3857 reference systems. After this transformation the resolution of the resulting raster model was $64 \mathrm{~m}$ for our test area. Next we have to choose the raster layers resolution for line generation. As the original sheet we wanted to make the comparison had a scale of 1:400.000 and considering the maximum hachure lines length as $4 \mathrm{~mm}$ and assuming one raster cell for one line, a 1600m resolution should be adopted. After the first attempts we realized that by such way the lines would have a larger distance between them as the methodology specifies (line length should be greater than the distance between them), being too sparse for an adequate visual interpretation. Reconsidering the situation we have modified the original resolution of $64 \mathrm{~m}$ to $200 \mathrm{~m}$, which will represent a 0.5 lines $/ \mathrm{mm}$ density on the map if it would be printed.

The next step was the computation of slope lines, in fact the generation of slope gradients lines. The slope lines were generated starting directly from the DEM values and represents one line for each raster cell. In the creation process it's possible to define the lines minimum and maximum length value as percent of raster layer resolution. For our test area we found that the best representation appears for $85 \%$ and $120 \%$. Best representations meaning that adjacent lines are close to each other but rarely touches each other.

In our point of view hachure maps shows towards on their content regarding the relief representation, representing artworks on a map, as elements of a communication language, how maps are sometimes considered (Vartic, 2015). The hachure lines not only have to reflect the reality but also should be have elegant representation with easy interpretation. We observed that if, the original elevation was used, even if it was converted to a lower resolution, the tiny terrain variations causes jumbled slope lines which considerably affects the interpretation of the result (Fig. 3).
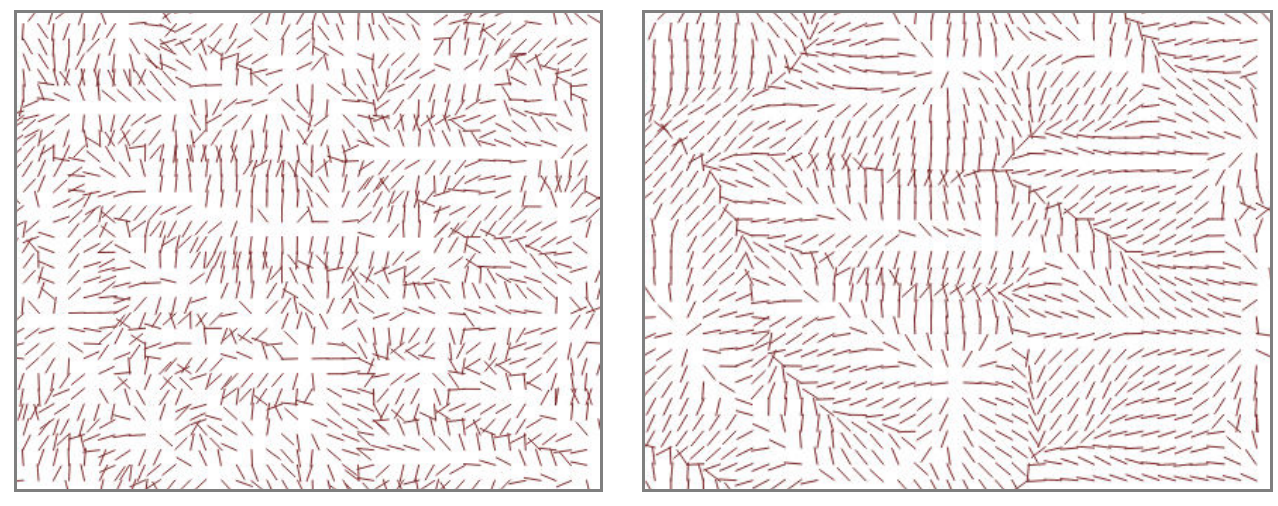

Fig. 3. Gradient lines extracted from unfiltered (left) and filtered (right) elevation model of the same location

To overcome this problem we used a smoothing Gauss filter over the DEM and applied the slope line extraction algorithm on the smoothed surface. By this way local variations of the surface were eliminated and we got a more coherent representation where general slope tendencies are more clearly visible. 


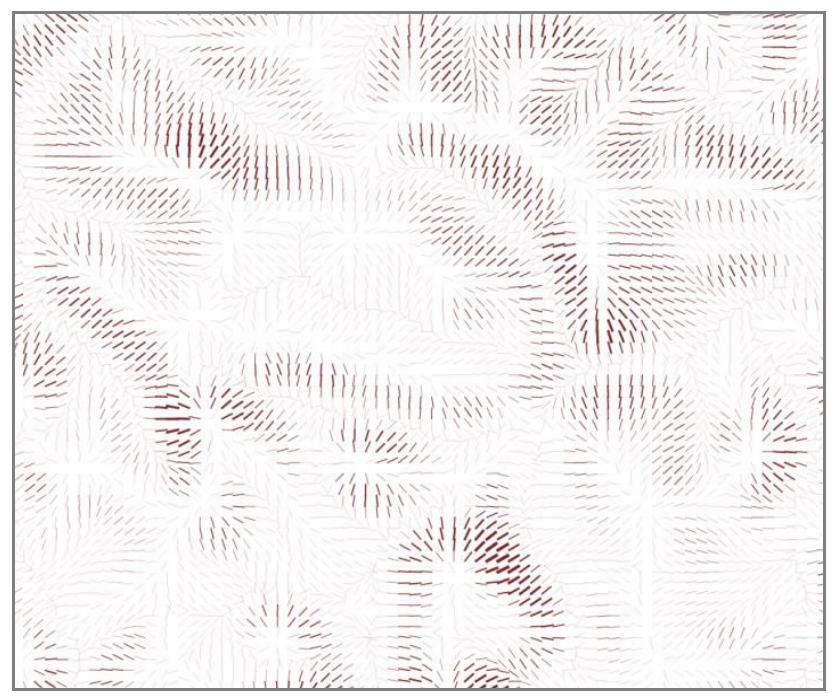

Fig. 4 Hachure lines thickness set to slope value

The resulted slope lines forms the basis of the hachure representation. Further on slope values were attached to each line for their thickness could be set (Fig. 4). For this we generated the slope layer using the original elevation model. For each slope line the slope values were taken at their end points and using an inverse distance weighted method the line's slope value was calculated.

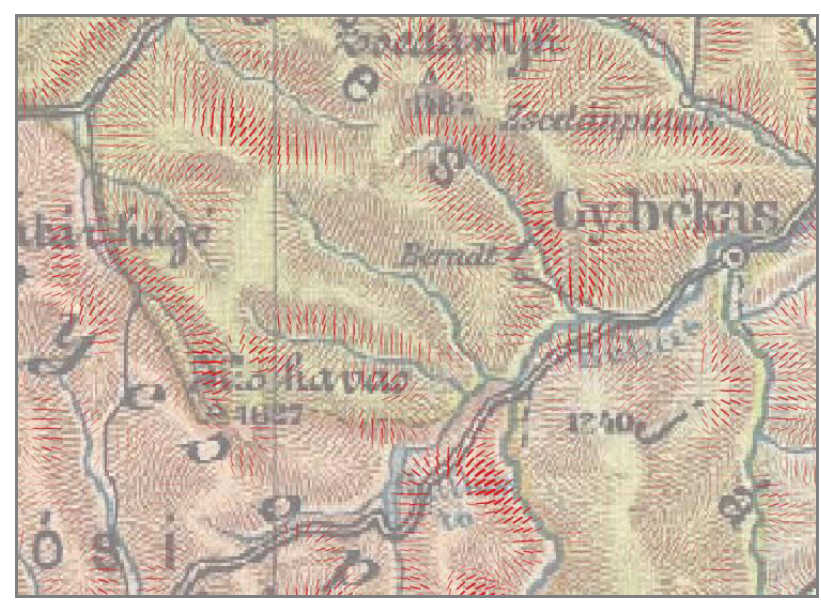

Fig. 5 Generated hachure lines (with red) over original map

Based on Lehmann's thickness classes the slope lines with under 5 degree were eliminated. As a result in the map has appeared little islands of several lines which had no meaning as they don't reflect any important morphological element. We decided to 
eliminate such little groups of slope lines. Because their detection in the vector layer has seemed more complicated we have identified and eliminated them in the raster layer with the slope values. For the maximum area for this islands we used an area of 20 hectares, representing at most 5 adjacent raster cells.

Fig. 5 shows a zoomed part of the generated hachure lines over the original map. It's observable that the steepest slopes are well represented and correctly positioned. However it seems that there are slopes in the original map where no generated hachure lines are present. In fact there are lines but are too narrow to be observable on the original map, but they can be identified as shown in Fig. 4.

\section{CONCLUSIONS}

Hachure lines automatic generation is possible using GIS technology. In the generation process the proper resolution and DEM filtering method have to be detected as the result to be fair and easy interpretable.

Hachure maps created in the past centuries are piece of arts in which global slope characteristics overrides local tendencies. As these maps were drawn at a specific scale, the automatic generation of hachure lines has to take account of the scale for which they are generated. For different scales different raster resolution should be adopted. To emphasize the general slope characteristics lower raster resolution and higher smoothing effect should be applied. Islands formed by several isolated lines can be also eliminated.

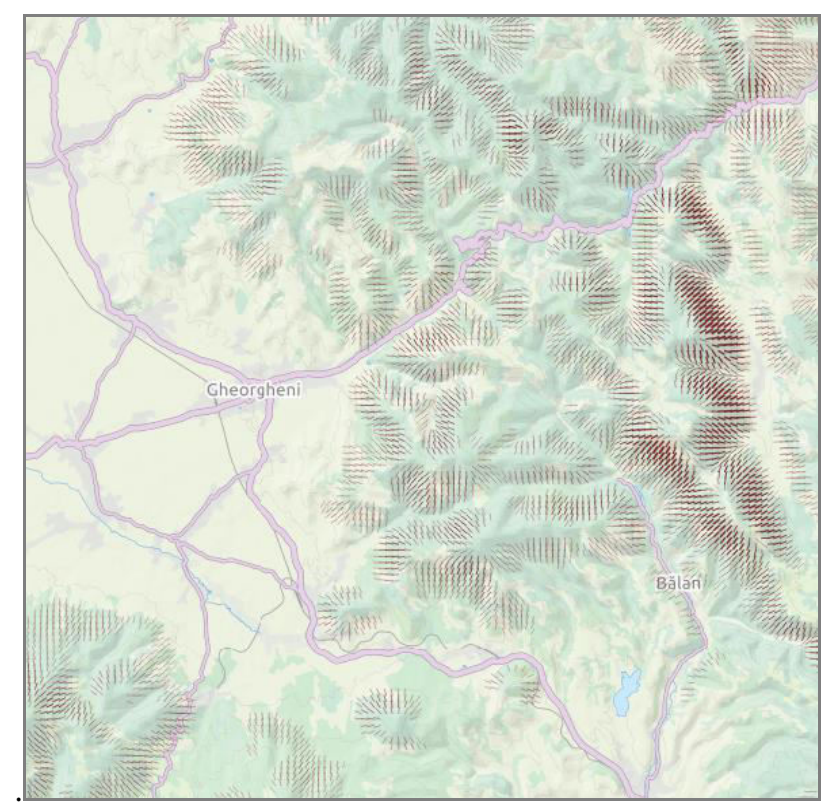

Fig. 6 Generated hachure lines over OpenStreetMaps

Beside existing application especially archeology, the resulted hachure representations also can be used as complementary relief representations even for existing maps (Fig. 6). In such cases shading can be used for 3D effect, while hachures characterizes the slopes. 


\section{ACKNOWLEDGMENT}

The presented research was supported by the DOMUS scholarship program of the Hungarian Academy of Sciences.

\section{R E F E R E N C E S}

Collier, P., Forrest, D. \& Pearson, A. (2003) The Representation of Topographic Information on Maps: The Depiction of Relief. The Cartographic Journal, 40 (1), 17-26.

Harsányi, M. (2010) Hegyvidékiterületek alternatív domborzatábrázolási módszerei, BSc Thesis, Eötvös Lóránd University, Budapest, 11-16.

Hicking, E.J. (2014) Maps and Mapping. A cartographic manual. Third edition, Canada, Simon Fraser University.

Hurni, L., Dahinden, T. \& Hutzler, E. (2001) Digital cliff drawing for topographic maps: traditional representations by means of new technologies. Cartographica, The International Journal for Geographic Information and Geovisualization 38(1), 55-65.

Imhof, E. (2007) Cartographic relief representation. California, ESRI Press.

Kennelly, P. J. \& Kimerling, A. J. (2000) Desktop Hachure Maps from Digital Elevation Models. Cartographic Perspectives, 37, 78-81.

Lysák, J. (2015) Digital rock drawing on Czech topographic maps: the current state and historical circumstances. AUC Geographica, 50 (2), 193-199.

Lysák, J. (2016) An algorithm for automated digital rock drawing in the style used in Czech topographic maps. AUC Geographica, 51 (1), 5-16.

Marston B. E. (2015) Improving the Representation of Large landforms in Analytical Relief Shading. Master Thesis, Oregon State University, Corvallis, Oregon.

Mélykúti, G. (2010) Topográfia 4: Domborzattan I., West Hungarian University.

Niculescu, G. (2003) Relief Plotting on Maps and in Geographical Studies in Time. Geographical Phorum, Geographical studies and environment protection researches, 2(2), 10-18.

O'Loughlin A. \& Mackaness, W. A. (1999) Automated Relief Representation for Visualisation of ArchaeologicalMonuments, In: ICA/ACI (eds.) Proceedings of the 19th International Cartographic Conference, Ottawa, Canada, International Cartographic Association, 1029-1035.

Räber, S., Jenny, B. \& Hurni, L. (2009) Swiss Style Relief Shading Methodology: Knowledge base for further development and application in digital cartography, In: ICA/ACI, IGM, Fisa S.A (eds.) Proceedings of the $24^{\text {th }}$ International Cartographic Conference ICC2009 Santiago de Chile, Chile, International Cartographic Association, 1-9.

Robinson, A. H., Morrison J. L., Muehrcke, P. C., Kimerling, A. J. \& Guptill, S.C. (1995) Elements of Cartography. Sixth Edition, New York, John Wiley and Sons.

Speich, D. (2009) Mountains Made in Switzerland: Facts and Concernsin Nineteenth-Century Cartography. Science in Context, 22 (3), 387-408.

Vartic, L. (2015) Cartographic visual expression, a means of communication and exploration in architecture and art. Geographia Technica, 10 (1), 90-95.

Yoeli, P. (1985) Topographic relief depiction by hachures with computer and plotter. Cartographic Journal, 22 (2), 111-124. 